\title{
The effects of international migration on the well- being of native populations in Europe
}

\author{
William Betz ${ }^{\top}$ and Nicole B Simpson ${ }^{2^{*}}$
}

\author{
* Correspondence: \\ nsimpson@colgate.edu \\ ${ }^{2}$ Department of Economics, Colgate \\ University and IZA, 13 Oak Dr, \\ Hamilton, New York 13346, USA \\ Full list of author information is \\ available at the end of the article
}

\begin{abstract}
Very little is understood about how immigrants affect the happiness, or subjective well-being of natives. We use the European Social Survey to analyze the effects of aggregate immigration flows on the subjective well-being of native-born populations in a panel of 26 countries between 2002 and 2010. We find that recent immigrant flows have a nonlinear, yet overall positive impact on the well-being of natives, with the largest effects coming from immigrant flows arriving in the previous year. Our results are small in magnitude and in practical application; only large immigrant flows would affect native well-being significantly.

JEL codes: F22, 131, 015

Keywords: International migration; Happiness; Life satisfaction
\end{abstract}

\section{Introduction}

With international migration reaching unprecedented levels of importance on both national and international policy agendas, the need for reliable studies that identify and analyze the trends and effects of migration has never been more crucial. As of 2010, an estimated 214 million people, or around 3.1 percent of the world's population, were classified as international migrants, living outside of their country of birth. With only 2.5 percent of the population, or 75 million people, living outside their country of birth in 1960 , this statistic illustrates a trend of increasing migration worldwide (United Nations Statistics Division 2006). With rapid increases in global population, environmental deterioration, aging populations in OECD countries, and globalization, it is highly unlikely that this statistic will reverse in the future (OECD, 2011). However, we do not have a clear picture of how international immigration affects the well-being of the native population in a given country. This is a topic of critical importance, as any debate on immigration policy revolves around the ultimate effects of migration on the welfare of native populations.

In this study, we combine individual level data from the first five rounds of the European Social Survey (ESS) with immigration and macroeconomic variables from the OECD to explore the potential effects of recent international migration on the self-reported wellbeing of a country's natives. Our results indicate that immigrant flows have statistically significant positive and nonlinear impacts on the happiness of natives, which vary in magnitude with the year of migrant inflows. For instance, immigrant flows lagged by one year have a larger impact on happiness of a country's population than immigrant flows lagged by two years. Immigration flows beyond the second year have statistically insignificant results. The variation in natives' well-being can be explained by a variety of factors, including

(C) 2013 Betz and Simpson; licensee Springer. This is an Open Access article distributed under the terms of the Creative Commons Attribution License (http://creativecommons.org/licenses/by/2.0), which permits unrestricted use, distribution, and reproduction in any medium, provided the original work is properly cited. 
immigrant assimilation, the inflexible European labor market, and the complementary effects of immigration on the country of migration. However, as a whole, the impacts are quite small, and only large influxes of immigrants would have significant effects on the happiness and life satisfaction of natives in the host countries.

These results, coupled with prior research on the impacts of immigration on natives, suggest that immigration may provide an overall benefit, albeit a small one, for a country's local population. These benefits could come through a variety of channels, including complementary factors of production, lower relative prices of goods and services produced by migrants, improved labor market efficiency, and economic growth resulting from higher demand for goods and services, job creation, and economies of scale (Borjas, 1995; Borjas, 2001; Borjas and Katz, 2005; Münz et al. 2006).

To date, relatively little research has been conducted on the specific relationship between migration and happiness. However, one recent paper by Akay et al. (2012) addresses a similar topic using the German Socio-Economic Panel (GSOEP) and INKAR datasets $^{1}$. Using a correlated random-effect model as their benchmark model, they study the impact of immigration rates on the overall well-being of both German-born natives and immigrants in Germany ${ }^{2}$. Their paper concludes that immigration provides a "robust, positive effect" on native well-being. The study also constructs indicators of assimilation to analyze how the effects of immigration may change when immigrants become further assimilated into the region. They find that when immigrants are not very assimilated, they have close to a zero effect on native well-being, but immigrants who are "intermediately assimilated" have the highest effect on native well-being (p.24). However, once immigrants become even more assimilated they again have zero effect on the population's well-being. While Akay et al. (2012) analyze immigration over a series of regions in Germany; we expand the scale of this study to a series of 26 countries and utilize the European Social Survey to analyze the impact of immigrants on a larger scale. Furthermore, we use an OLS (Ordinary Least Squares) fixed effects regression with lagged immigration variables as our benchmark model.

Other related literature provides interesting background when approaching the topic of happiness and migration. Specifically, Polgreen and Simpson (2011) used the World Values Survey to discover a U-shaped relationship between emigration rates and happiness: emigration decreases as happiness increases in relatively unhappy countries, but rises as happiness increases in relatively happy countries. Furthermore, migration has been shown to negatively affect the happiness of family members left in the home country and that migrants, on average, tend to have a lower happiness score than non-migrants, suggesting that migrants may be mistaken in thinking that moving will increase happiness (Borraz et al., 2008; Bălțătescu, 2007; Knight and Gunatilaka, 2010; Bartram, 2010, 2011). While these studies do not specifically address the welfare impacts that migrants have on native populations, they provide an interesting perspective on how happiness, or the perception of happiness, affects migration decisions and outcomes ${ }^{3}$.

Though there is a relative lack of research examining immigration and native well-being, there are a multitude of studies that explore other channels through which migration affects the native population, from wages and labor market performance to internal immigration rates and population growth. It is these studies that provide a large impetus for our research. If immigrants have significant impacts on the native population in other important manners, there could be a significant correlation between migration and native happiness. 
David Card, one of the prominent researchers looking at the impacts of immigration on natives, has sought to explore the specific effects of migration on the population of the United States. Card (2001) found that immigration flows have a small negative impact on the wages of low-skilled natives and did not cause large native outflows. He also found a small negative relationship between immigration and native employment rates. It is important to note that the magnitude of the estimated impacts of immigrants were small, with immigration (during the 1980s) reducing wages and employment rates in high migrant cities by one to three percent. His results confirm those of other studies, such as Friedberg and Hunt (1995), Card (1990), Butcher and Card (1991), and Card and Lewis (2007), which conclude that there are small effects, if any at all, of immigration on U.S. wages. Card (2007) also shows that immigrants have small but non-negligible effects on the welfare of U.S. natives through a variety of other factors, including increased housing prices, expanded tax base, undesirable "peer group" effects, and the hindrance of "effective" governance.

Borjas and Katz (2005) provide another perspective on the impact of immigration on U.S. natives. They find that the increased number of low-skill immigrants over the past several decades, mainly from Mexico, has negatively affected the wages of low-skilled natives and has benefitted those who are highly skilled ${ }^{4}$. This result confirms Borjas' (2003) study in which he found that the wages of competing workers were lowered by 3 to 4 percent for every 10 percent increase in immigrant supply. In his 2003 study, Borjas states that immigration "substantially worsened the labor market opportunities faced by many native workers" (p. 1370). However, he does recognize some of the potential advantages of immigration. He reports that natives could benefit from relative price decreases of low-skill intensive goods and services, increased labor market efficiency, and production complementarities (Borjas, 1995; Borjas, 2001; Borjas and Katz, 2005).

While studies performed by Borjas and Card have focused on immigration into the U.S., several studies focus on European immigration. Staffolani and Valentini (2010) examine the impact of immigration on the Italian labor market. They assert that all natives in the so-called "regular sector" experience increased wages with immigration flows. However, they also differentiate between white- and blue-collar jobs, stating that while natives with white-collar jobs always benefit from immigration, blue-collar natives can either win or lose depending on a variety of immigration factors. A similar study conducted by Falzoni et al. (2007) asserted that immigration negatively affected Italian blue-collar wages, but white-collar wages were not significantly affected. Other studies, conducted using data from Spain and the United Kingdom, countries that have both seen large immigration increases over recent decades ${ }^{5}$, conclude that employment and wage rates are not significantly affected by immigration shocks (Carrasco et al., 2008; Dustmann et al., 2005). Several studies have also examined the complementary aspects of immigration in Europe. Dustmann et al. (2003) notes that empirical evidence suggests that immigration flows enhanced wage growth in the UK. In Italy, another study illustrated that migrants actually increased the wages of national manual workers (Gavosto et al., 1999). However, others, including Angrist and Kugler (2002), contend that the inflexible labor market institutions in Europe, encompassing firing costs, restrictive collective bargaining agreements, rigid wages, and high business entry costs, will most likely exacerbate the pain caused by immigration to natives in the long-run. 
In fact, Angrist and Kugler (2002) find that increased immigration is negatively associated with native employment rates in a panel of European countries. Furthermore, Boeri (2010) contends that native perceptions of immigrants worsen during periods of recession.

These studies depict the large potential for immigration to have both adverse and beneficial effects on the native population of a country. Some of the factors that immigration has been shown to affect, such as wages and employment, are also correlated with happiness ${ }^{6}$. Therefore; it could be likely that immigration is also correlated with measurements of subjective well-being and happiness, thus motivating our study.

Given the nature of the ESS cross-sectional data that we use to study the relationship between happiness and migration inflows, endogeneity is a potential issue. While we can examine how the happiness and immigration are associated, current theory does not provide us with the information necessary to determine the direction of causality (Simpson, 2013). Even though we tend to frame the discussion in the mindset that migrants could possibly have an effect on the happiness of natives, one should keep in mind that it could be happiness (or lack thereof) of the native population that attracts (or dissuades) migrants from moving to the native country. We account for endogeneity through the use of multiple lagged independent variables, specifically regarding our main variable of interest, immigration flows. Utilizing lagged immigration variables also enables us to analyze any dynamic effects that immigrant flows may have on native well-being. In addition, we include country fixed effects in our analysis which should help to alleviate endogeneity.

\section{Empirical specification}

The determinants of well-being can be modeled as:

$$
W_{i, k, t}=\alpha+\beta_{1} X_{i, k, t}+\beta_{2} F_{k, t-y}+\varepsilon_{i, k, t}
$$

where $W_{i, k, t}$ is the self-reported measure of well-being of individual $i$ in country $k$ in time period $t$ and $X_{i, k, t}$ is a series of variables that account for a variety of socioeconomic and demographic factors that may impact happiness. The error term, $\varepsilon_{i, k, t}$, accounts for unobservable factors and measurement error in our model. For instance, so-called "exaggeration" effects ${ }^{7}$ caused by individuals not being able to objectively report their well-being would be captured by our error term (Frey and Stutzer, 2002). The estimated coefficients are represented by $\alpha, \beta_{1}$, and $\beta_{2}$. Because immigration flows in a given time period may not have immediate effects on the native population, whether direct, indirect, or merely perceived, it is necessary to account for immigration flows in previous years, represented by $F_{k, t-y}$ where $y$ represents the lag structure.

Equation (1) provides the basis for the benchmark specification of our empirical equations. Substituting happiness as our measure of well-being and including all controlling variables and fixed effects, we get our baseline empirical specification:

$$
\begin{aligned}
\text { Happiness }_{i, k, t}=\alpha & +\beta_{1} \log \left(F_{k, t-y}\right)+\beta_{2}\left\{\log \left(F_{k, t-y}\right)\right\}^{2}+\beta_{3} E U_{k, t}+F E_{t}+F E_{k}+\beta_{4} X_{i, k, t} \\
& +\beta_{5} Y_{k, t}+\varepsilon_{i, k, t}
\end{aligned}
$$

where the dependent variable is the happiness index of individual $i$ in country $k$ at time period $t$. Our independent variables of interest are those concerning immigration flows. Each term is composed of the lagged immigration flows $F$ (in thousands) into country $k$ 
in time period $t-y$. We take the natural logarithm of immigration flows, and square the terms to consider non-linear relationships. The immigration flow variables can take large values, so taking the natural logarithm produces estimated coefficients of similar magnitude to the other control variables ${ }^{8}$. In fact; Simpson and Sparber (2013) justify the use of natural logarithms for immigrant flow variables.

To control for additional factors that may influence the relationship between happiness and immigration flows, we also include time $\left(F E_{t}\right)$ and country $\left(F E_{k}\right)$ fixed effects in the model. We have a dummy variable 'EU' that takes a one if a country is in the European Union at a given time $t$, and zero otherwise. Finally, multiple control variables on both the individual $\left(X_{i, k, t}\right)$ and macroeconomic level $\left(Y_{k, t}\right)$ are included, which are discussed in detail in the next section.

In addition to examining the impact of immigration on happiness, we also explore the influence of migration on overall life satisfaction. Thus, we also substitute happiness with a measure of life satisfaction and compare the results with our baseline specification.

\section{Data}

Due to the relative richness of European immigration data, the primary data source used for examining our model is the European Social Survey (ESS, 2013). The ESS is a multistage cross-sectional survey conducted biannually that covers over 30 nations, both within and outside of the European Union (EU). The survey was established in 2001 and is currently conducting its sixth round. For the purposes of this study, we utilize the cumulative dataset composed of the first five survey rounds (2002, 2004, 2006, 2008 and 2010). In addition, we use only countries that had enough immigration data available over the rounds they participated in. This left us with 26 observable countries, each with at least two rounds of ESS data containing approximately 500 to 2,000 respondents each (reported in Table 1).

\section{a. Subjective measures of well-being}

As a relatively new subject of research, self-reported well-being measures have been greeted with some skepticism within the economic community. Because such measures are subjective and cannot be directly observed, unlike most data utilized by economists, some economists have rejected them as "unscientific." In addition, some argue that such measures are too simplistic and do not present meaningful data (Frey and Stutzer, 2002). If this is the case, economists studying happiness would be presented with significant problems when analyzing and interpreting results. However, recent papers by Di Tella and MacCulloch (2006), Frey and Stutzer (2002), Kahneman and Krueger (2006), and Layard (2006) suggest that the study of happiness within economics can bring about meaningful and beneficial results to the profession, especially in regard to policy formation.

Kahneman and Krueger (2006) provide several key arguments for the benefits of using such data, not the least of which include more accurate welfare analysis and a greater understanding of how to maximize societal welfare. Layard (2006) complements this discussion by advocating for the use of happiness in the field of economics, stating that better theory and policy would result from greater "insights of revealed preference" 
Table 1 Number of observations by country and year (in the sample using ESS data)

\begin{tabular}{|c|c|c|c|c|c|c|}
\hline \multirow[b]{2}{*}{ Country } & \multirow[b]{2}{*}{ Total observations } & \multicolumn{5}{|c|}{ Observations by year } \\
\hline & & 2002 & 2004 & 2006 & 2008 & 2010 \\
\hline Austria (AT) & 3,728 & 1,269 & 1,142 & 1,317 & - & - \\
\hline Belgium (BE) & 6,549 & 1,271 & 1,228 & 1,404 & 1,397 & 1,249 \\
\hline Bulgaria (BG) & 4,764 & - & - & 1,032 & 1,769 & 1,963 \\
\hline Cyprus (CY) & 2,395 & - & - & 756 & 967 & 672 \\
\hline Czech Republic (CZ) & 5,442 & 829 & 1,748 & - & 1,313 & 1,552 \\
\hline Denmark (DK) & 6,185 & 1,201 & 1,211 & 1,226 & 1,295 & 1,252 \\
\hline Finland (FI) & 7,142 & 1,725 & 1,802 & 1,661 & 1,954 & - \\
\hline France (FR) & 7,186 & 1,129 & 1,380 & 1,554 & 1,689 & 1,434 \\
\hline Germany (DE) & 10,190 & 2,113 & 1,945 & 1,947 & 2,056 & 2,129 \\
\hline Hungary (HU) & 6,101 & 1,408 & 1,231 & 1,203 & 1,098 & 1,161 \\
\hline Ireland (IE) & 6,883 & 1,512 & 1,591 & 1,034 & 1,292 & 1,454 \\
\hline Israel (IL) & 3,080 & 1,136 & - & - & 1,015 & 929 \\
\hline Italy (IT) & 1,590 & 611 & 979 & - & - & - \\
\hline Luxembourg (LU) & 1,158 & 563 & 595 & - & - & - \\
\hline Netherlands (NL) & 7,566 & 1,879 & 1,471 & 1,488 & 1,391 & 1,337 \\
\hline Norway (NO) & 7,605 & 1,832 & 1,572 & 1,547 & 1,353 & 1,301 \\
\hline Poland (PL) & 6,916 & 1,718 & 1,364 & 1,342 & 1,255 & 1,237 \\
\hline Portugal (PT) & 4,039 & 972 & 1,096 & 1,065 & 906 & - \\
\hline Russia (RU) & 5,692 & - & - & 1,806 & 1,934 & 1,952 \\
\hline Slovakia (SK) & 4,096 & - & 832 & 948 & 1,173 & 1,143 \\
\hline Slovenia (SI) & 4,721 & 1,058 & 931 & 1,017 & 862 & 853 \\
\hline Spain (ES) & 5,555 & 905 & 923 & 1,004 & 1,431 & 1,292 \\
\hline Sweden (SE) & 7,579 & 1,646 & 1,631 & 1,559 & 1,512 & 1,231 \\
\hline Switzerland (CH) & 5,687 & 1,272 & 1,341 & 1,132 & 1,032 & 910 \\
\hline Turkey (TR) & 3,500 & - & 1,594 & - & 1,906 & - \\
\hline United Kingdom (GB) & 8,026 & 1,582 & 1,332 & 1,669 & 1,769 & 1,674 \\
\hline Total & 143,375 & 27,631 & 28,939 & 27,711 & 32,369 & 26,725 \\
\hline
\end{tabular}

(p. C33). In fact, Layard believes that "the prime purpose of social science should be to discover what helps and hinders happiness" (p. C32).

One does, however, have to treat happiness measures with caution. Special considerations must be taken into account when comparing individuals across cultures and time. Di Tella and MacCulloch (2006) mention that interpersonal comparisons of happiness indicators among small numbers of individuals continue to be problematic. According to their research, these problems can be attributed to an "exaggeration" effect, where individuals scale their happiness differently from others. That being said, it has been seen that these problems are reduced dramatically when the number of individuals being compared increases. With over 140,000 observations being used in each regression, "exaggeration" effects and any other biases due to comparing small numbers of individuals should virtually disappear from this study. In addition, a gamut of recent studies has lent increasing legitimacy to the practice of comparing well-being over both time and countries ${ }^{9}$. Our study utilizes country fixed effects to account for any differences in mentality or culture among countries. 
The ESS provides two separate measures of individual well-being: happiness and life satisfaction. The following questions were asked during the survey process:

- "Taken all things together, how happy would you say you are?"

- "All things considered, how satisfied are you with your life as a whole nowadays?"

Both of these questions were answered on a 0 to 10 scale, with 0 being "extremely unhappy/ dissatisfied" and 10 being "extremely happy/extremely satisfied." Several studies have shown a high correlation between life satisfaction and happiness (Schyns, 1998; Blanchflower and Oswald, 2004). Other studies have shown that there is a distinct difference between the two measures. Stevenson and Wolfers (2008) have revealed that life satisfaction and happiness measure certain variables differently (e.g. GDP per capita) and that there is a psychological difference between the two concepts. We therefore include both measures in our analysis.

\section{b. Immigration}

We next discuss the control variables. First, the immigrant status of ESS respondents proved to be slightly problematic as the ESS does not directly ask whether one is a native of the country or not. However, the survey does ask a series of questions relating to immigration status, including whether the respondent was born in the survey country and whether they had citizenship status in that country. For this paper, we use a strict classification of natives, by classifying them as those who were both born in and had citizenship in the survey country. Under this classification, $9.0 \%$ of respondents over the 5-year cumulative ESS dataset were considered non-native and were excluded from our analysis.

To obtain immigration flow statistics for each of the 26 countries used in the study, we utilize the international migration database of the OECD $(2012)^{10}$. This allowed us to acquire immigration statistics for not only the year that the survey was conducted but also for the three years preceding the immigration. We were then able to merge these immigration statistics with the ESS database.

In addition to happiness and immigration data, several socioeconomic controls also needed to be included in the regressions as controls. Based on the findings of previous studies, we decided to include variables for income, gender, age, health status, education level, religiosity, and children at home. Also included were several macroeconomic variables for each country, including real GDP growth rate and the civilian unemployment rate. We now describe each of these variables.

\section{c. Income}

One of the most controversial topics in happiness research has centered on the relationship between income and happiness. Easterlin (1974) found that while individual happiness increases with rising income, increases in real GDP per capita across society are not associated with rising happiness. Therefore, one's subjective well-being will change with increases in income, but will change inversely with the increase in the income of those around them. Easterlin's conclusions have led many to believe that income is not strongly linked to individual well-being above a certain threshold where basic needs are fully met ${ }^{11}$. Nevertheless, Ball and Chernova (2008) published a study 
with results contradictory to Easterlin's conclusion. They assert that changes in both relative and absolute income have significant impacts on the well-being of an individual. This result is also confirmed by Frijters et al. (2004), who found that large increases in real household income following the reunification of East and West Germany were associated with increases in life satisfaction.

To analyze the effect of income in our study, two issues needed to be addressed. First, all income reported by the ESS was recorded in brackets (or ranges), rather than discrete numbers. To deal with the income brackets, we followed a technique similar to that used by Ball and Chernova (2008) and Bartram (2011), using the midpoint of each income bracket as an approximation of the individual's family income in Euros. For the highest bracket, in which there was no upper bound, we use a figure equal to $120 \%$ of the lower bound of the bracket to acquire an approximate income value. The second issue we had to contend with was that income was recorded as two separate questions within the cumulative ESS data file. The first question (\#43 - hinctnt) was asked during the first three rounds of the survey. It asked individuals to add up their household's total net income from all sources and then report which letter on a queue card corresponded to their income bracket in Euros. Respondents could report their income in the most familiar method to them: weekly, monthly, or annually ${ }^{12}$. A second measurement of income was used by the ESS in the fourth and fifth rounds of the survey. This measure also dealt with household total income, but the categories of income were regionally based and distinctive for each country. As a result, income brackets were based in local currency and needed to be converted into Euros before being combined with the first measure of income. Using conversion rates given in the ESS Round 4. Appendix 5 and ESS Round 5 Appendix 2, all income was converted into Euros and then combined with the income categories from the first three rounds ${ }^{13}$. All income measures were then converted into 2005 Euros using the European Central Bank Harmonized Index of Consumer Prices.

\section{d. Other control variables}

Beyond measures of income, several additional variables were included to control for a variety of demographic effects. First, to account for any possible differences in gender, a dummy variable 'female' was created that takes a one if the respondent is female and zero otherwise. We also included a variable to account for the well-documented association between age and measures of subjective well-being. The ESS includes observations for individuals aged 14 or older. Due to several studies confirming a quadratic relationship between age and happiness/life satisfaction indicators ${ }^{14}$, it was necessary to account for age as well as age-squared.

Several noteworthy studies have confirmed the result established by Helliwell and Putnam (2004) that self-assessed health status is a strong contributing factor to life satisfaction and happiness. Ball and Chernova (2008), Safi (2010), and Bartram (2011) all have found that health was a significant variable in relation to life satisfaction. The ESS asked individuals to rate their general health on a 1-5 scale, with 1 being 'very good' and 5 being 'very bad'. Approximately 60 percent of our sample reported having better than 'fair' health. Due to this bias, we decided to include health status as a series of dummy variables: Very Good, Good, Fair, and Poor. Very poor health served as our 
omitted variable in all regressions. Including self-reported health status has other benefits as well. Helliwell and Putnam (2004) state that "including self-reported health among the predictors of subjective well-being...has the added advantage of tending to offset the effects of any 'positivity' or 'optimism' response bias, because such a response bias ought to affect both self-assessed health and subjective well-being" (p. 1440).

Helliwell and Putnam (2004) note that there is a slight positive correlation between education and happiness. However, they explain that this impact may be due to the correlation between higher education and increased health, and that education may in fact have no direct impact on measures of well-being. To confirm this result, we employ a continuous variable that accounts for the number of years of education for an individual.

Our study also includes controls for the marital status of an individual. Since the ESS survey recorded marital status using different questions in different rounds, it was necessary to combine each round's status into a series of dummy variables. Therefore, we created a series of five dummies: Married, Separated, Divorced, Widowed, and Single. Since some survey rounds accounted for civil partnership status in various manners, we treated all civil partnerships as if they were marriages. In all regressions, the dummy variable for Single served as our omitted variable.

Several recent studies have illustrated the importance of religion in one's subjective well-being. While studying life satisfaction in Israel, Van Praag et al. (2010) found that there were differences in life satisfaction indicators between religions (e.g. Muslim populations had, on average, a lower life satisfaction than Christians in Israel). Helliwell and Putnam (2004) note that "more frequent interactions with other people in both church and community settings tend to increase the extent to which those individuals think that others can be trusted and thereby to enhance their subjective well-being" (p. 1441). Their research also determined that it is possible to differentiate between the subjective measures of religiosity, such as religious belief, and more objective ones, such as "church" attendance frequency. In addition, Ball and Chernova (2008) conclude that happiness of an individual is positively correlated with increased religious importance. As such, we include a measure from the ESS on how religious an individual is ${ }^{15}$. One's self reported answer to how religious they are will be referred to as their religiosity.

Children have also been shown to be a statistically significant factor in the life satisfaction of an individual. Ball and Chernova (2008) find that people with two or more children were, on average, more satisfied than those who did not have any children. However, people with only one child were not statistically more satisfied than those without any. The ESS includes a variable in which individuals denote whether they have a child living at home during the time of the survey or not.

To control for macroeconomic trends that could potentially spur or hinder immigration flows into a country, we include several key macroeconomic variables in our regressions. All macroeconomic variables included in our analysis (e.g. real GDP growth and civilian unemployment rate) were retrieved from the OECD (2012) statistical database and are specific to each country.

\section{e. Summary statistics}

Using the first five rounds of ESS data, we were able to obtain a large sample of natives for our analysis, composed of 143,375 observations from 26 countries. There is large 
variation in immigration flows between countries. The three countries within the dataset with the largest average annual immigration flows over the past decade are Germany $(614,810)$, Spain $(537,299)$, and the United Kingdom $(346,587)$. Those with the smallest inflows are the Slovak Republic $(8,836)$, Finland $(12,828)$, and Luxembourg $(13,100)$, as reported in Table 2. As is expected, countries with larger populations tend to have larger immigration flows. All summary statistics use the proper weighting of the cumulative ESS dataset for our study ${ }^{16}$.

There are also significant differences in happiness and life satisfaction across our panel of countries (reported in Table 3). Denmark had the highest overall happiness (8.350) as well as the highest overall life satisfaction (8.497). Behind Denmark, Switzerland and Finland both have very high happiness levels (8.121 and 8.032, respectively). The countries with the lowest overall happiness are Turkey (6.1), Russia (6.08), and Bulgaria (5.33).

As commonly expected, we find that the distribution of real income was skewed to the right. To correct for this, we took the natural log of all income measures. We found that the mean real income was approximately $€ 22,122$ with a standard deviation of $€ 22,473$ (in $2005 €$ ).

Table 2 Average immigration flows

\begin{tabular}{|c|c|c|}
\hline Country & Average immigration inflows (thousands) ${ }^{2}$ & Standard deviation (SD) \\
\hline Germany & 614.81 & 44.303 \\
\hline Spain & 537.299 & 235.503 \\
\hline United Kingdom & 364.587 & 88.889 \\
\hline Italy & 314.151 & 137.651 \\
\hline Russian Federation & 234.319 & 88.249 \\
\hline Turkey & 162.945 & 13.63 \\
\hline France & 122.328 & 19.728 \\
\hline Switzerland & 108.477 & 23.598 \\
\hline Austria & 86.916 & 11.781 \\
\hline Netherlands & 82.605 & 14.641 \\
\hline Belgium & 77.771 & 16.791 \\
\hline Sweden & 58.026 & 19.035 \\
\hline Ireland & 50.709 & 23.563 \\
\hline Czech Republic & 47.205 & 30.71 \\
\hline Portugal & 42.273 & 39.414 \\
\hline Norway & 37.15 & 12.79 \\
\hline Poland & 31.689 & 9.585 \\
\hline Israel & 31.388 & 20.638 \\
\hline Denmark & 24.616 & 6.168 \\
\hline Hungary & 23.003 & 4.835 \\
\hline Cyprus & 16.815 & 4.053 \\
\hline Bulgaria & 14.482 & 8.626 \\
\hline Slovenia & 14.038 & 9.59 \\
\hline Luxembourg & 13.1 & 2.019 \\
\hline Finland & 12.828 & 4.038 \\
\hline Slovak Republic & 8.836 & 4.608 \\
\hline
\end{tabular}


As seen in Table 4, the means of the remainder of the control variables are as expected. The average age in the study is $46.4,53 \%$ of observations are female, and at 12.08 , the average number of years of education is roughly equivalent to completion of secondary education. Finally, $55.7 \%$ of the sample is married, $25.8 \%$ is single, $7.9 \%$ is widowed, $7.3 \%$ is divorced, and only $1.2 \%$ of the sample identify as separated.

\section{Results}

The primary question being addressed in this paper is whether or not immigration flows, as a whole, have a statistically significant effect on the well-being of native populations in a given country. We first address the results and significance of our benchmark empirical model, with happiness as our dependent variable. We then conduct robustness checks, specifically looking at specifications with alterations in our immigration, individual, macro, and interaction terms. Finally, we compare the results of our regressions with life satisfaction as the dependent variable with those using happiness.

It is important to note that we cluster the standard errors by countries to alleviate any concern arising from serial correlation (as pointed out by Bertrand et al., 2004). This may be important as the immigration regressor varies only at the country-year

Table 3 Overall happiness and life satisfaction by country (sorted by overall happiness)

\begin{tabular}{|c|c|c|c|c|}
\hline Country & Overall happiness & SE & Overall life satisfaction & SE \\
\hline Denmark (DK) & 8.350 & 0.017 & 8.497 & 0.018 \\
\hline Switzerland $(\mathrm{CH})$ & 8.121 & 0.020 & 8.143 & 0.023 \\
\hline Finland (FI) & 8.032 & 0.017 & 7.951 & 0.018 \\
\hline Norway (NO) & 7.951 & 0.017 & 7.829 & 0.019 \\
\hline Luxembourg (LU) & 7.911 & 0.060 & 7.851 & 0.070 \\
\hline Sweden (SE) & 7.903 & 0.018 & 7.892 & 0.019 \\
\hline Netherlands (NL) & 7.816 & 0.016 & 7.681 & 0.018 \\
\hline Belgium (BE) & 7.757 & 0.019 & 7.452 & 0.022 \\
\hline Ireland (IE) & 7.624 & 0.025 & 7.277 & 0.028 \\
\hline Austria (AT) & 7.609 & 0.033 & 7.631 & 0.035 \\
\hline Israel (IL) & 7.595 & 0.042 & 7.235 & 0.049 \\
\hline Cyprus (CY) & 7.558 & 0.038 & 7.258 & 0.039 \\
\hline Spain (ES) & 7.553 & 0.024 & 7.267 & 0.026 \\
\hline United Kingdom (GB) & 7.541 & 0.022 & 7.135 & 0.025 \\
\hline France (FR) & 7.267 & 0.023 & 6.385 & 0.032 \\
\hline Germany (DE) & 7.258 & 0.020 & 6.985 & 0.023 \\
\hline Slovenia (SI) & 7.161 & 0.029 & 6.853 & 0.032 \\
\hline Poland (PL) & 6.868 & 0.026 & 6.462 & 0.030 \\
\hline Czech Republic (CZ) & 6.842 & 0.031 & 6.482 & 0.034 \\
\hline Slovakia (SK) & 6.643 & 0.040 & 6.215 & 0.045 \\
\hline Portugal (PT) & 6.584 & 0.037 & 5.558 & 0.044 \\
\hline Italy (IT) & 6.373 & 0.058 & 6.692 & 0.059 \\
\hline Hungary (HU) & 6.275 & 0.036 & 5.516 & 0.037 \\
\hline Turkey (TR) & 6.100 & 0.065 & 5.974 & 0.071 \\
\hline Russia (RU) & 6.082 & 0.034 & 5.390 & 0.038 \\
\hline Bulgaria (BG) & 5.330 & 0.042 & 4.517 & 0.043 \\
\hline Average & 7.235 & 0.031 & 6.928 & 0.035 \\
\hline
\end{tabular}


Table 4 Summary statistics

\begin{tabular}{lcccc}
\hline Variable & Mean & Std. dev. & Min & Max \\
\hline Age & 46.42 & 17.751 & 14 & 110 \\
\hline Female & 0.527 & 0.499 & 0 & 1 \\
\hline Real Income* & $22,122.10$ & $22,473.28$ & 900 & 144,000 \\
\hline Years of Education & 12.087 & 4.06 & 0 & 56 \\
\hline Religiosity & 4.602 & 2.95 & 0 & 10 \\
\hline Child & 0.434 & 0.496 & 0 & 1 \\
\hline Very Bad Health & 0.014 & 0.119 & 0 & 1 \\
\hline Bad Health & 0.081 & 0.273 & 0 & 1 \\
\hline Fair Health & 0.306 & 0.461 & 0 & 1 \\
\hline Good Health & 0.428 & 0.495 & 0 & 1 \\
\hline Very Good Health & 0.169 & 0.375 & 0 & 1 \\
\hline Married & 0.557 & 0.494 & 0 & 1 \\
\hline Separated & 0.012 & 0.11 & 0 & 1 \\
\hline Divorced & 0.073 & 0.26 & 0 & 1 \\
\hline Widowed & 0.079 & 0.27 & 0 & 1 \\
\hline Single & 0.258 & 0.438 & & 0 \\
\hline
\end{tabular}

* Income is recorded in 2005 Euros.

level, but the dependent variable consists of micro-level data that varies across individuals within countries over time. All of the reported standard errors are corrected for heteroskedasticity and are clustered at the country level.

The benchmark results (Table 5) are presented in multiple sections: immigration variables, macro controls, and demographic controls ${ }^{17}$. By examining the results of our immigration variables, the first lag term of immigrant flows yields a positive coefficient, while the second lag term yields a negative coefficient, and both are significant at the $1 \%$ level or better. This suggests that perhaps the effect of immigrants on the happiness of natives changes the longer the immigration population stays in the host country. In addition, the magnitude of the estimated coefficient is larger (in absolute value) for the second lag, indicating that immigrant flows have slightly varying impacts on happiness over time. Our estimation also indicates that the squared-terms for immigrant flows are both significant, suggesting a non-linear relationship between lagged immigrant flows and the happiness of natives.

In fact, when evaluating the differential effect of increases in immigrant flows, we find an overall positive effect on happiness. For example, our estimates for the first lag of immigrant flows suggest that the net effect of a ten percent increase in immigrant flows scale (at the sample mean) increases the happiness of natives by approximately 0.07 points on a 0 to 10 . The linear term causes a 0.0589 point increase in happiness, but the squared-term leads to a 0.012 increase, thus a gain in 0.0709 points, holding all other variables constant ${ }^{18}$. If the increase in immigration occurred two years earlier, the impact on native happiness would be, on average, smaller at 0.002 (at the sample mean); the negative effects in the linear term are negated by the positive effects in the squared term. While we report positive impacts of immigration, even the largest effects would be relatively small. It is important to note the small magnitude of our results are to be expected, as immigration is likely to have a small overall impact on native well- 
Table 5 Benchmark results: regression of happiness on immigration flows

\begin{tabular}{|c|c|c|}
\hline & \multicolumn{2}{|c|}{ (1) } \\
\hline & \multicolumn{2}{|c|}{ Happiness } \\
\hline \multicolumn{3}{|l|}{ Immigration Variables } \\
\hline Ln (Immflow1YearLag) & $0.589^{* * *}$ & {$[0.190]$} \\
\hline Ln (Immflow2YearLag) & $-0.747^{* * *}$ & {$[0.248]$} \\
\hline$[$ Ln (Immflow1YearLag)]^2 & $-0.0143^{* * *}$ & {$[0.00473]$} \\
\hline$[$ Ln (Immflow2YearLag)]^2 & $0.0913^{* * *}$ & {$[0.0321]$} \\
\hline \multicolumn{3}{|l|}{ Macro Controls } \\
\hline EU & $0.226^{* *}$ & {$[0.0901]$} \\
\hline Real GDP Growth Rate & $0.0624^{* *}$ & {$[0.0251]$} \\
\hline Unemployment Rate & -0.0211 & {$[0.0132]$} \\
\hline \multicolumn{3}{|l|}{ Demographic Controls } \\
\hline Age & $-0.0655^{* * *}$ & {$[0.00636]$} \\
\hline $\mathrm{Age}^{\wedge} 2$ & $0.000678^{* * *}$ & {$[0.000059]$} \\
\hline Ln(Real Income) & $1.021^{* * *}$ & {$[0.312]$} \\
\hline$[$ Ln(Real Income) $] \wedge 2$ & $-0.0381^{* *}$ & {$[0.0181]$} \\
\hline Bad Health & $0.876^{* * *}$ & {$[0.119]$} \\
\hline Fair Health & $1.636^{* * *}$ & {$[0.120]$} \\
\hline Good Health & $2.197^{* * *}$ & {$[0.125]$} \\
\hline Very Good Health & $2.694^{* * *}$ & {$[0.136]$} \\
\hline Female & $0.134^{* * *}$ & {$[0.0294]$} \\
\hline Married & $0.537^{* * *}$ & {$[0.0443]$} \\
\hline Separated & $-0.392^{* * *}$ & {$[0.0832]$} \\
\hline Divorced & $-0.147^{* * *}$ & {$[0.0403]$} \\
\hline Widow & $-0.166^{* *}$ & {$[0.0702]$} \\
\hline Years of Education & $0.0179^{* * *}$ & [0.00528] \\
\hline Child At Home & -0.0401 & {$[0.0277]$} \\
\hline Ln(Religiosity) & $0.272^{* * *}$ & {$[0.0387]$} \\
\hline Year Fixed Effects & $\nabla$ & \\
\hline Country Fixed Effects & $\nabla$ & \\
\hline Intercept & -1.447 & [1.602] \\
\hline N & 143375 & \\
\hline R-Squared & 0.226 & \\
\hline
\end{tabular}

*Statistically Significant at the $10.0 \%$ Level.

**Statistically Significant at the $5.0 \%$ Level.

***Statistically Significant at the $1.0 \%$ Level.

Clustered Heteroskedasticity-Robust Standard Errors in Brackets.

being compared to more relevant issues to natives, such as one's subjective health or marriage status.

Immigration flows lagged by one year provide a slightly larger positive impact on the happiness of natives than immigration flows lagged by two years. Additional tests were performed with immigration lags up to four years prior: three and four year lags were found to be statistically insignificant.

The impact of immigrants may differ over time for several reasons. First, more recent migrants may have had little or no time to settle and/or impact the native population of the country. Secondly, it is possible that this result is due to the inflexible European labor market. That is, immigration flows from different years may have varying impacts 
on the local labor market due to rigidities and time constraints. This could be especially true if migrants mainly impact the local population through labor market interactions. As Akay et al. (2012) suggest when the economic outcomes of immigrants converge with that of natives, there may initially be utility generating benefits for natives, such as complementary factors of production, lower relative prices of goods and services produced by migrants, and improved labor market efficiency. But, this convergence may ultimately result in increased labor market competition, resulting in decreased utility for natives. Finally, these differences could be due to heterogeneity in immigration cohorts. As Borjas (1989) states, immigration cohorts change in characteristics over time due to the adaptation and assimilation processes. These changes could include increases in productivity and changes in skill levels. As a result, immigrants from different time periods should not be considered to be a homogenous group. Our results confirm this, showing that immigrants over several years have differing impacts on the native populations. This may well be attributable to the assimilation process, or to changes in the composition of migrant patterns ${ }^{19}$.

In addition, the findings of previous researchers who look at the impact of immigration on natives ${ }^{20}$ also suggest that immigration has a small impact, if any at all, on native populations. While we find significant effects, the magnitude of the effects are relatively small, given all other factors. For instance, compared to one's subjective health status, where having 'very good' health status has a relatively large and significant effect on native well-being ${ }^{21}$, holding all other factors constant, immigration flows have negligible impact on one's happiness. Furthermore, our study's findings seem to reflect similar magnitudes as the results of Akay et al. (2012).

The second section of Table 5 illustrates the results of our regression that are specifically focused on macroeconomic control variables. We can see that the macroeconomic variables have the signs that one would expect intuitively. A one percentage point increase in real GDP growth is associated with an approximate 0.062 increase in one's self-reported happiness, which is statistically significant at the $1 \%$ level. We find no significant relationship between aggregate unemployment and the happiness of natives. Also included in our regressions are year fixed effects and an indicator variable for EU membership. We find that the coefficients for the 2004, 2006, and 2008 dummies are negative, compared to our 2002 base year. While the 2010 dummy is statistically insignificant, all other year dummies are statistically significant at the $10 \%$ level or better. This suggests that there are important differences in the well-being of natives over time that are not being captured by our control variables, consistent with the work of Easterlin (2002), Veenhoven (1996), and Ehrhardt et al. (2000). In addition, our EU dummy suggests that respondents who lived in a country that transferred from non-EU to EU status experienced a 0.226 increase in happiness, on average, after the change in country status. This increase could be due to any changes in culture, policy, law, etc. that may come with EU accession.

The third section of our table depicts the results for our demographic control variables in our primary models. Every control variable is statistically significant at the $10 \%$ level or better, with the exception of having children in the home. In line with the results of other researchers ${ }^{22}$, we find a U-shaped relationship between happiness and age, with happiness being the lowest at an age of approximately 48. In addition, improved health, increased education, heightened religiosity, and being female are all 
associated with increases in happiness. Our results also indicate that real income has a positive effect on happiness up to a certain point, at which point additional income has diminishing impacts on happiness.

While the primary model is specified correctly, it is important to perform checks on the robustness of such a model to ensure that our results are consistent across multiple specifications, which are reported in Tables 6 and 7. In regression 2, we only include lagged immigration flows from one year prior and its square. The coefficients on our variables of interest become insignificant in this model. This result suggests that the inclusion of immigration flows from two years prior is necessary for the proper interpretation of our results. Regression 3 (in Table 6) only includes a linear term for immigration flows from one year ago. This term captures the overall positive effect of immigration from one year ago, and confirms our results from our benchmark model. In regression 4, we only include immigration flows from two years prior. In this regression, our coefficients indicate that, on average, a $10 \%$ in immigration flows two years ago would have a 0.0056 increase in happiness, on a scale of 0 to 10 , holding all other variables in our model constant. This result also confirms our benchmark model. Finally, regression 5 shows what happens when we do not include the squared term from our robustness check with only immigration flows from two years ago. Our coefficient on immigration flows in this model becomes statistically insignificant and reflects a smaller impact of immigration from two years ago than our benchmark model.

Table 7 shows a continuation of robustness checks. In regression 6, all year fixed effects are removed from our model. We can see that this change causes several changes on our immigration variables. Mainly, the EU dummy and GDP growth rate are now insignificant at the $10 \%$ confidence level. In addition, the positive effects of immigration flows lagged one year are slightly larger. These results suggest that year fixed effects play an important role in accounting for the effect of immigration flows on the happiness of natives.

In regression 7, we remove the two macroeconomic controls and find that all immigration flow variables become statistically insignificant at the $10 \%$ level, indicating that the inclusion of macroeconomic variables is necessary to obtaining proper results in our model.

Removing all income variables from our regressions also provided us with evidence that our benchmark model is in fact robust with all of the estimated coefficients being larger (in absolute value terms) compared to the benchmark. This result indicates that the inclusion of income is necessary to prevent the overestimation of the effect of immigration on native happiness.

In order to provide a more detailed story on the impacts of immigration on native happiness, we also include several interaction terms in our regressions (the results are available upon request). First, we add an interaction between current immigration flows and real GDP growth to see if there is an association between GDP growth and immigrant flows and find that the signs and significance on the immigration flow variables are similar, but the estimated coefficients on the interaction terms are not significant. The results are similar when we interact immigration flows with years of education (of the native), suggesting that the effects on native well-being due to immigration do not depend on the education level of the native. 
Table 6 Robustness checks

\begin{tabular}{|c|c|c|c|c|}
\hline & (2) & (3) & (4) & (5) \\
\hline & $\overline{\text { Happiness }}$ & $\overline{\text { Happiness }}$ & $\overline{\text { Happiness }}$ & Happiness \\
\hline \multicolumn{5}{|l|}{ Immigration Variables } \\
\hline \multirow[t]{2}{*}{ Ln (Immflow1YearLag) } & -0.109 & 0.0801 & - & - \\
\hline & {$[0.227]$} & {$[0.0765]$} & - & - \\
\hline \multirow[t]{2}{*}{ Ln (Immflow2YearLag) } & - & - & $-0.420^{* *}$ & 0.00232 \\
\hline & - & - & {$[0.203]$} & {$[0.00203]$} \\
\hline \multirow[t]{2}{*}{ Ln (Immflow1YearLag)]^2 } & 0.00499 & - & - & - \\
\hline & {$[0.00624]$} & - & - & - \\
\hline \multirow[t]{2}{*}{ Ln (Immflow2YearLag)]^2 } & - & - & $0.0566^{* *}$ & - \\
\hline & - & - & {$[0.0258]$} & - \\
\hline \multicolumn{5}{|l|}{ Year Dummies } \\
\hline \multirow[t]{2}{*}{2004} & $-0.153^{* *}$ & $-0.144^{* *}$ & $-0.165^{* * *}$ & $-0.150^{* *}$ \\
\hline & {$[0.0563]$} & {$[0.0521]$} & {$[0.0587]$} & {$[0.0553]$} \\
\hline \multirow[t]{2}{*}{2006} & $-0.203^{* * *}$ & $-0.196^{* *}$ & $-0.230^{* * *}$ & $-0.201^{* *}$ \\
\hline & {$[0.0722]$} & {$[0.0738]$} & {$[0.0804]$} & {$[0.0729]$} \\
\hline \multirow[t]{2}{*}{2008} & $-0.106^{*}$ & $-0.100^{*}$ & $-0.108^{*}$ & $-0.105^{*}$ \\
\hline & {$[0.0551]$} & {$[0.0568]$} & {$[0.0558]$} & {$[0.0554]$} \\
\hline \multirow[t]{2}{*}{2010} & -0.0279 & -0.0234 & -0.0645 & -0.0278 \\
\hline & {$[0.0695]$} & {$[0.0686]$} & [0.0839] & [0.0690] \\
\hline Macro Controls & $\nabla$ & $\nabla$ & $\nabla$ & $\nabla$ \\
\hline Demographic Controls & $\nabla$ & $\nabla$ & $\nabla$ & $\nabla$ \\
\hline Country Fixed Effects & $\nabla$ & $\nabla$ & $\nabla$ & $\nabla$ \\
\hline N & 143375 & 143375 & 143375 & 143375 \\
\hline R-Squared & 0.225 & 0.225 & 0.225 & 0.225 \\
\hline
\end{tabular}

*Statistically Significant at the $10.0 \%$ Level.

**Statistically Significant at the $5.0 \%$ Level.

*** Statistically Significant at the $1.0 \%$ Level.

Clustered Heteroskedasticity-Robust Standard Errors in Brackets.

We also include an interaction term that interacts immigration flows with the migrant stock of a country ${ }^{23}$, and find that the impact of migrants does not hinge on the size of a country's foreign population stock. Immigrant flows remain statistically significant, with similar signs and magnitudes as our benchmark model.

Finally, Table 8 depicts a comparison between our (benchmark) happiness and life satisfaction models. One can see that the difference between using life satisfaction and happiness as a measure of subjective well-being is small in this instance. This is not surprising given the results of Blanchflower and Oswald (2004) as well as Schyns (1998). The main difference seems to be consistently higher, albeit marginally, standard errors when using life satisfaction. However, in line with the conclusions of many researchers, it cannot be concluded that there is one particular advantage of one measure of subjective well-being over another in every circumstance.

\section{Conclusion}

The goal of this study is to analyze the effects of aggregate immigration flows into a given country on the well-being, both happiness and life satisfaction, of native 
Table 7 Robustness checks

\begin{tabular}{|c|c|c|c|}
\hline & (6) & (7) & (8) \\
\hline & $\overline{\text { Happiness }}$ & $\overline{\text { Happiness }}$ & Happiness \\
\hline \multirow[t]{2}{*}{ Ln (Immflow1YearLag) } & $0.730^{* * *}$ & 0.316 & $0.752^{* * *}$ \\
\hline & {$[0.250]$} & {$[0.405]$} & {$[0.216]$} \\
\hline \multirow[t]{2}{*}{ Ln (Immflow2YearLag) } & $-0.766^{* * *}$ & -0.320 & $-0.920^{* * *}$ \\
\hline & {$[0.238]$} & {$[0.312]$} & {$[0.241]$} \\
\hline \multirow[t]{2}{*}[\operatorname{Ln}(\operatorname{Immflow}1\text{YearLag})]{$\wedge 2$} & $-0.0189^{* * *}$ & -0.00416 & $-0.0184^{* * *}$ \\
\hline & [0.00653] & {$[0.0117]$} & [0.00529] \\
\hline \multirow[t]{2}{*}[\operatorname{Ln}(Immflow2YearLag)]{$\wedge 2$} & $0.0921^{* * *}$ & 0.0165 & $0.120^{* * *}$ \\
\hline & {$[0.0286]$} & {$[0.0392]$} & [0.0319] \\
\hline \multirow[t]{2}{*}{ EU } & 0.130 & $0.388^{*}$ & $0.245^{* * *}$ \\
\hline & {$[0.105]$} & {$[0.209]$} & {$[0.0791]$} \\
\hline \multirow[t]{2}{*}{ Real GDP Growth Rate } & 0.0375 & - & $0.0665^{* *}$ \\
\hline & [0.0228] & - & {$[0.0267]$} \\
\hline \multirow[t]{2}{*}{ Unemployment Rate } & $-0.0272^{* *}$ & - & $-0.0282^{* *}$ \\
\hline & {$[0.0115]$} & - & [0.0123] \\
\hline \multirow[t]{2}{*}{ Ln(Real Income) } & $1.075^{* * *}$ & $1.061^{* * *}$ & - \\
\hline & {$[0.317]$} & {$[0.322]$} & - \\
\hline \multirow[t]{2}{*}[\text{Ln(RealIncome)}]{$\wedge 2$} & $-0.0408^{* *}$ & $-0.0400^{* *}$ & - \\
\hline & [0.0183] & [0.0184] & - \\
\hline \multirow[t]{2}{*}{2004} & - & -0.0653 & $-0.159^{* * *}$ \\
\hline & - & {$[0.0708]$} & {$[0.0556]$} \\
\hline \multirow[t]{2}{*}{2006} & - & $-0.0711^{*}$ & $-0.298^{* * *}$ \\
\hline & - & [0.0405] & {$[0.0843]$} \\
\hline \multirow[t]{2}{*}{2008} & - & -0.109 & $-0.169^{* * *}$ \\
\hline & - & {$[0.0858]$} & {$[0.0571]$} \\
\hline \multirow[t]{2}{*}{2010} & - & 0.0157 & -0.109 \\
\hline & - & {$[0.108]$} & {$[0.0881]$} \\
\hline Demographic Controls & $\nabla$ & $\nabla$ & $\square$ \\
\hline Country Fixed Effects & $\nabla$ & $\nabla$ & $\square$ \\
\hline \multirow[t]{2}{*}{ Intercept } & -1.802 & -1.466 & $3.892^{* * *}$ \\
\hline & {$[1.774]$} & {$[1.780]$} & {$[0.580]$} \\
\hline N & 143375 & 143375 & 143375 \\
\hline R-squared & 0.225 & 0.224 & 0.214 \\
\hline
\end{tabular}

*Statistically Significant at the $10.0 \%$ Level.

** Statistically Significant at the $5.0 \%$ Level.

***Statistically Significant at the $1.0 \%$ Level.

Clustered Heteroskedasticity-Robust Standard Errors in Brackets.

populations. While this study is only a preliminary exploration of a relatively unexplored topic, its findings could have important implications for future immigration policy. Most previous research has focused on specific impacts of immigration on areas of the native population's life, focusing on labor market implications and often giving contradicting results. Our study was the first to utilize the European Social Survey to examine the impact of international migration inflows on a native population's subjective well-being across multiple nations.

The results of this study indicate that aggregate immigrant flows into a given country do in fact have a positive effect on the subjective well-being of native populations, with 
Table 8 OLS regression results - happiness vs. life satisfaction

\begin{tabular}{|c|c|c|}
\hline & Benchmark & \\
\hline & Happiness & Life satisfaction \\
\hline \multirow[t]{2}{*}{ Ln (Immflow1YearLag) } & $0.589^{* * *}$ & $0.655^{*}$ \\
\hline & {$[0.190]$} & {$[0.327]$} \\
\hline \multirow[t]{2}{*}{ Ln (Immflow2YearLag) } & $-0.747^{* * *}$ & $-0.741^{* *}$ \\
\hline & {$[0.248]$} & {$[0.329]$} \\
\hline \multirow[t]{2}{*}{ Ln(Immflow1YearLag)]^2 } & $-0.0143^{* * *}$ & $-0.0178^{*}$ \\
\hline & {$[0.00473]$} & {$[0.00905]$} \\
\hline \multirow[t]{2}{*}[\operatorname{Ln}(Immflow2YearLag)]{$\wedge 2$} & $0.0913^{* * *}$ & $0.100^{* *}$ \\
\hline & {$[0.0321]$} & {$[0.0384]$} \\
\hline \multirow[t]{2}{*}{$\mathrm{EU}$} & $0.226^{* *}$ & 0.157 \\
\hline & {$[0.0901]$} & {$[0.147]$} \\
\hline \multirow[t]{2}{*}{ Intercept } & -1.447 & -0.637 \\
\hline & {$[1.602]$} & [1.547] \\
\hline Macro Controls & $\nabla$ & $\nabla$ \\
\hline Demographic Controls & $\nabla$ & $\nabla$ \\
\hline Year Fixed Effects & $\square$ & $\nabla$ \\
\hline Country Fixed Effects & $\nabla$ & $\nabla$ \\
\hline $\mathrm{N}$ & 143375 & 143375 \\
\hline R-Squared & 0.226 & 0.236 \\
\hline
\end{tabular}

recent immigration flows (one-year lagged) having a slight positive impact on the selfreported happiness of natives and more assimilated migrants (two-year lagged) having smaller positive impacts on native welfare. After two years, the effects of immigration on native populations become statistically insignificant. However, it is important to note that the overall effects of migration on natives are very small. As a result, only large immigration shocks would have a palpable effect on the well-being of native populations.

When the conclusions of this study are combined with prior research on the impact of immigration on native populations, it becomes evident that immigration likely has a net positive impact on the welfare of natives. As a result, one could infer that the costs of immigration, such as marginally negative wage and employment impacts for natives, could easily be balanced or even surpassed by the benefits of migration, such as improved labor market efficient, aggregate economic growth, and lower relative prices of immigrant produced goods and services.

However, research on this topic remains scarce, and the exact channels through which immigration impacts the well-being of immigrants have not yet been pinpointed. Further research could examine the specific happiness impacts of immigrant groups of various human capital levels, demographic factors, and length of stay on native populations. The amount of interaction between immigrants in the destination country could also have a significant influence on how immigrants affect the happiness of natives. In order to carry out future research, more detailed datasets combining disaggregated immigration statistics and happiness are necessary. 


\section{Endnotes}

${ }^{1}$ INKAR stands for Indikatoren und Karten zur Raumentwicklung. This dataset contains local labor market characteristics and crucial immigration information that Akay et al. (2012) utilized in combination with the GSOEP dataset.

${ }^{2}$ The paper also provides estimates using OLS, ordered probit, random-effects and fixedeffects models. However, with few exceptions, all models provide similar estimates.

${ }^{3}$ For further background on happiness research as it relates to migration, we refer the reader to Simpson (2013).

${ }^{4}$ Another study conducted by Ottaviano and Peri (2012) finds that immigration has a positive impact on high-skilled native wages and a small negative impact on low-skilled native wages.

${ }^{5}$ Gonzalez and Ortega (2009) note that Spanish provinces gained, on average, 17\% of their initial workforce in immigration flows between 1998 and 2008. In the UK, immigration flows have increased by approximately 65\% from 2000 to 2009 according to OECD data.

${ }^{6}$ See Ohtake (2012), Clark and Oswald (1994), Van Praag and Ferrer-i-Carbonell (2002), Gerlach and Stephan (1996), and Blanchflower and Oswald (2004).

${ }^{7}$ See section IIIa for more information about exaggeration effects.

${ }^{8}$ However, our results are robust to a linear specification in immigration flows, with point estimates in the $10^{-4}$ range.

${ }^{9}$ See Frey and Stutzer (2002), Layard (2005), Kahneman and Krueger (2006), Helliwell (2007), Easterlin and Angelescu (2010), Safi (2010), Polgreen and Simpson (2011), and Stevenson and Wolfers $(2008,2009)$.

${ }^{10}$ Supplementary data for non-OECD countries was obtained from Eurostat and the World Bank (2013) statistical databases.

${ }^{11}$ See Bartram (2010, 2011), Frey and Stutzer (2002), and Clark et al. (2008).

${ }^{12}$ For the purpose of this study, all income figures were calculated annually.

${ }^{13}$ For further information on income measurements used in the ESS, see the European Social Survey Cumulative File Study Description ESS (2011).

${ }^{14}$ See Oswald (1997), Blanchflower and Oswald (2004), Ball and Chernova (2008), and Popova and Otrachshenko (2011).

${ }^{15}$ The exact question regarding religiosity is worded in the ESS as follows: "Regardless of whether you belong to a particular religion, how religious would you say you are?"

${ }^{16}$ For more information on the proper weighting of the cumulative ESS dataset, see http://ess.nsd.uib.no/ess/doc/Weighting_ESS_cumulative_data.pdf

17 "Immflow" represents the immigrant flows in our regression tables. Lagged variables will include an added specification indicating how many years they are lagged by. For instance, immigration flows that are lagged two years will be denoted as "Immflow2YearLag."

${ }^{18}$ Where appropriate, all results are evaluated using the sample mean of 4.213. Therefore, the evaluation of the squared term is calculated as follows: $\frac{2 \beta_{2} \ln \left(F_{t-y}\right)}{10}$ for a 10 percentage point increase in immigrant flows.

${ }^{19}$ Unfortunately, we could not obtain a dataset that decomposes immigrant flows according to labor market skills or education level. 
${ }^{20}$ Examples include Card (2007), Card and Lewis (2007), and Dustmann et al. (2005).

${ }^{21} \mathrm{~A}$ result confirmed by other researchers, including Ball and Chernova (2008), Safi (2010), and Bartram (2011).

${ }^{22}$ See Oswald (1997), Blanchflower and Oswald (2004), Ball and Chernova (2008), and Popova and Otrachshenko (2011).

\section{Competing interests}

The IZA Journal of Migration is committed to the IZA Guiding Principles of Research Integrity. The authors declare that they have observed these principles.

\section{Acknowledgements}

The authors would like to thank seminar participants at Colgate University and the conference on Migration: Global Development, New Frontiers at University College London in 2013. We also thank Martin Guzi for sharing his data with us, and an anonymous referee. We thank the Division of Social Sciences at Colgate University who funded Betz through a summer research grant in 2012.

Responsible editor: Amelie F Constant

\section{Author details}

'Department of Economics, Colgate University, 13 Oak Dr, Hamilton, New York 13346, USA. ${ }^{2}$ Department of Economics, Colgate University and IZA, 13 Oak Dr, Hamilton, New York 13346, USA.

Received: 25 April 2013 Accepted: 3 July 2013

Published: 1 August 2013

\section{References}

Akay A, Constant A, Giuletti C (2012) The impact of immigration on the well-being of natives. IZA Discussion Paper No. 6630 http://ftp.iza.org/dp6630.pdf

Angrist J, Kugler A (2002) Protective or counter-productive? Labor market institutions and the effect of immigration on EU natives. IZA Discussion Paper No. 433 http://ftp.iza.org/dp433.pdf

Ball R, Chernova K (2008) Absolute income relative income and happiness. Social Indicators Research 88(3):497-529

Bălțătescu S (2007) Central and eastern European migrant's subjective quality of life. A comparative study. Journal of Identity and Migration Studies 1(2):67-81

Bartram D (2010) International migration open borders debates and happiness. International Studies Review 12:339-361

Bartram D (2011) Economic migration and happiness: Comparing immigrants' and natives' happiness gains from income. Social Indicators Research 103(1):57-76

Bertrand M, Duflo E, Mullainathan S (2004) How much should we trust differences-in-differences estimates? The Quarterly Journal of Economics 119(1):249-275

Blanchflower D, Oswald A (2004) Well-being over time in Britain and the USA. Journal of Public Economics 88:1359-1386 Boeri T (2010) Immigration to the land of redistribution. Economica 77:651-687

Borjas G (1989) Economic theory and international migration. International Migration Review 23(3):457-485

Borjas G (1995) The economic benefits from immigration. The Journal of Economic Perspectives 9(2):3-22

Borjas G (2001) Does immigration grease the wheels of the labour market? Brookings Papers on Economic Activity 1:69-119

Borjas $G$ (2003) The labor demand curve is downward sloping: Re-examining the impact of immigration on the labor market. The Quarterly Journal of Economics 118(4):1335-1374

Borjas G, Katz L (2005) The evolution of the Mexican-born workforce in the United States. National Bureau of Economic Research Working Paper 11281

Borraz F, Rossi M, Pozo S (2008) And what about the family back home? International migration and happiness. Working Paper Universidad de la Republica Documento No. 03/08 http://decon.edu.uy/publica/2008/0308.pdf

Butcher K, Card D (1991) Immigration and wages: Evidence from the 1980s. American Economic Review 81 (2):292-296

Card D (1990) The impact of the Mariel boatlift on the Miami labor market. Industrial and Labor Relations Review 43 (1):245-257

Card D (2001) Immigrant inflows native outflows and the local labor market impacts of higher immigration. Journal of Labor Economics 19(1):22-64

Card D (2007) How immigration affects US cities. CReAM Discussion Paper no 11/07 http://davidcard.berkeley.edu/ papers/immig-affect-us.pdf

Card D, Lewis E (2007) The diffusion of Mexican immigrants during the 1990s: Explanations and impacts. In: Borjas G (ed) Mexican immigration to the United States. University of Chicago Press

Carrasco R, Jimeno J, Ortega A (2008) The effect of immigration on the labor market performance of native-born workers: Some evidence for Spain. Journal of Population Economics 21(3):627-648

Clark A, Oswald A (1994) Unhappiness and unemployment. The Economic Journal 104(424):648-659

Clark A, Frijters P, Shields M (2008) Relative income happiness and utility: An explanation for the Easterlin paradox and other puzzles. Journal of Economic Literature 46(1):95-144

Di Tella R, MacCulloch R (2006) Some uses of happiness data in economics. Journal of Economic Perspectives 20(1):25-46

Dustmann C, Fabbri F, Preston I, Wadsworth J (2003) The local labour market effects of immigration in the UK. Home Office Online Report 06/03 http://eprints.ucl.ac.uk/14331/1/14331.pdf

Dustmann C, Fabbri F, We P (2005) The impact of immigration on the British labour market. The Economic Journal 115 (November):F324-F341

Easterlin R (1974) Does economic growth improve the human lot? Some empirical evidence. In: David P, Reder M (ed) Nations and households in economic growth: essays in honour of Moses Abramovits. Academic Press, New York and London 
Easterlin R (2002) Is reported happiness five years ago comparable to present happiness? A cautionary note. Journal of Happiness Studies 3(2):193-198

Easterlin R, Angelescu L (2010) Happiness and growth the world over: Time series evidence on the happiness-income paradox. In: Hinte H, Zimmermann K (ed) Happiness growth and the life cycle. Oxford University Press, New York

Ehrhardt J, Saris W, Veenhoven R (2000) Stability of life-satisfaction over time: Analysis of change in ranks in a national population. Journal of Happiness Studies 1(2):177-205

Euro Stat (2013) European Commission, European Union, Luxembourg. http://epp.eurostat.ec.europa.eu/portal/page/ portal/eurostat/home. Accessed 2 March 2013

European Social Survey (2011) Study Description, Norwegian Social Science Data Services, Norway

European Social Survey (2013) Cumulative File, Norwegian Social Science Data Senvices, Norway

Falzoni A, Venturini A, Villosio C (2007) Skilled and unskilled wage dynamics in Italy in the 90s: Changes in the individual characteristics institutions trade and technology. Laboratorio R. Revelli Working Paper Series 61. Centre for Employment Studies, Italy

Frey B, Stutzer A (2002) What can economists learn from happiness research? Journal of Economic Literature 40(2):402-435

Friedberg R, Hunt J (1995) The impact of immigration on host country wages employment and growth. Journal of Economic Perspectives 9(2):23-44

Frijters P, Haisken-DeNew J, Shields M (2004) Money does matter! Evidence from increasing real income and life satisfaction in East Germany following reunification. American Economic Review 94:730-740

Gavosto A, Venturini A, Villosio C (1999) Do immigrants compete with natives? Labour 13(3):603-622

Gerlach K, Stephan G (1996) A paper on unhappiness and unemployment in Germany. Economic Letters 52(3):325-330

Gonzalez L, Ortega F (2009) Immigration and housing booms: evidence from Spain. IZA Discussion Paper no. 4333 http://ftp.iza.org/dp4333.pdf

Helliwell J (2007) Well-being and social capital: Does suicide pose a puzzle? Social Indicators Research 81:455-496

Helliwell J, Putnam R (2004) The social context of well-being. Philosophical Transactions-Royal Society of London Series B 359:1435-1446

Kahneman D, Krueger A (2006) Developments in the measurement of subjective well-being. Journal of Economic Perspectives 20(1):3-24

Knight J, Gunatilaka R (2010) Great expectations? The subjective well-being of rural-urban migrants in China. World Development 38(1):113-124

Layard R (2005) Happiness: lessons from a new science. Penguin, London

Layard R (2006) Happiness and public policy: A challenge to the profession. The Economic Journal 116:C24-C33

Münz R, Straubhaar T, Vadean F, Vadean N (2006) The costs and benefits of European immigration (Report No. 3). Migration Research Group, Hamburg Institute of International Economics (HWWI)

OECD (2011) International migration outlook 2011 OECD iLibrary, Paris, France http://www.oecd-ilibrary.org/socialissues-migration-health/international-migration-outlook-2011_migr_outlook-2011-en

OECD (2012) OECD Stat Extract (database). OECD iLibrary, Paris, France http://stats.oecd.org/

Ohtake F (2012) Unemployment and happiness. Japan Labor Review 9(2):59-74

Oswald A (1997) Happiness and economic performance. Economic Journal 107:1815-1831

Ottaviano G, Peri G (2012) Rethinking the effects of immigration on wages. Journal of European Economic Association 10(1):152-197

Polgreen L, Simpson N (2011) Happiness and international migration. Journal of Happiness Studies 12(5):819-840

Popova O, Otrachshenko V (2011) Life (Dis) satisfaction and decision to migrate: Evidence from central and eastern Europe. Osteuropa-Institut Regensburg Working Paper (306) http://ssrn.com/abstract=1982502

Safi M (2010) Immigrants' Life satisfaction in Europe: between assimilation and discrimination. European Sociological Review 26(2):159-171

Schyns P (1998) Cross national differences in happiness: Economic and cultural factors explored. Social Indicators Research 43(1/2):3-26

Simpson N (2013) Happiness and migration. In: Zimmermann K, Constant A (ed) International handbook on the economics of migration. Edward Elgar Publishing Limited http://www.iza.org/MigrationHandbook/21_Simpson_Happiness\%20and\% 20Migration.pdf

Simpson N, Sparber C (2013) The short- and long-Run determinants of unskilled immigration into US. Southern Economic Journal (in press), States

Staffolani S, Valentini E (2010) Does immigration raise blue and white collar wages of natives? The case of Italy. Labour 24(3):295-310

Stevenson B, Wolfers J (2008) Economic growth and subjective well-being: Reassessing the Easterlin Paradox. Brookings Papers on Economic Activity 39(1):1-102

Stevenson B, Wolfers J (2009) The paradox of declining female happiness. American Economic Journal: Economic Policy 1 (2):190-225

United Nations Statistics Division (2006) Demographic yearbook (volume 3). New York, NY Retrieved from website: http:// unstats.un.org/unsd/demographic/products/dyb/dybcens.htm

Van Praag B, Ferrer-i-Carbonell A (2002) Life satisfaction differences between workers and non-workers: The value of participation per se. Amsterdam Tinbergen Institute. Tinbergen Institute Discussion Paper TI 2002-018/3 http:// papers.tinbergen.nl/02018.pdf

Van Praag B, Romanov D, Ferrer-i-Carbonell A (2010) Happiness and financial satisfaction in Israel: Effects of religiosity ethnicity and war. Journal of Economic Psychology 31(6):1008-1020

Veenhoven R (1996) Developments in satisfaction research. Social Indicators Research 37:1-46

World Bank (2013) World data bank. Washington, DC http://databank.worldbank.org/data/home.aspx. Accessed 2 March 2013

doi:10.1186/2193-9039-2-12

Cite this article as: Betz and Simpson: The effects of international migration on the well-being of native populations in Europe. IZA Journal of Migration 2013 2:12. 